\title{
Pharmacokinetic Profile of Ciprofloxacin Fine Granule Compared to Ciproxan ${ }^{\circledR}$ Tablet
}

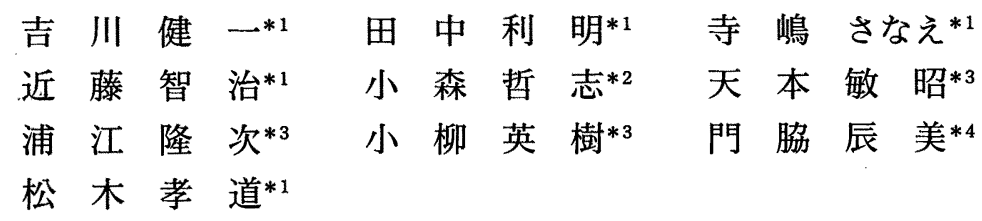

Ciprofloxacin (Ciproxan $\left.^{\circledR}, \mathrm{CPFX}\right)$ fine granule which was newly developed for easier oral administration, is expected to be advantageous considering elderly patients' drug compliance.

\section{Objectives}

To investigate the pharmacokinetics of a new fine granule formulation of CPFX and its bioequivalency to Ciproxan ${ }^{\otimes} 200 \mathrm{mg}$ tablet in healthy volunteers.

\section{Methods}

Sixteen healthy male volunteers aged between 20 and 25 years were enrolled in an open, 2-period crossover study. Fine granule containing $200 \mathrm{mg}$ CPFX (containing 232.8mg CPFX hydrochloride) and one Ciproxan $200 \mathrm{mg}$ tablet (containing 232.8mg CPFX hydrochloride) were administered orally to each volunteer in fasting condition with one-week washout.

\section{Pharmacokinetic evaluation}

Plasma concentration of CPFX was determined at before and $0.25,0.5,1,1.5,2,3,4,6,8,12$ and $24 \mathrm{~h}$ after dosing of each formulation. Pharmaco-kinetic parameters $\mathrm{C}_{\max }, \mathrm{t}_{\max }, \mathrm{AUC}$ and $\mathrm{t} 1 / 2$ were calculated. To investigate the bioequivalence between two formulations, ANOVA was performed in $\mathrm{C}_{\max }$ and AUC $0-\infty$, and $90 \%$ confidence intervals of the difference were given. Significant level

\footnotetext{
*1 バイエル薬品(侏開発/臨床薬理

テ 532 大阪市淀川区宮原 3-5-36

*2 バイエル薬品(侏)企画解析

*3 医療法人相生会臨床薬理センター

*4. 侏日本医学臨床検査研究所
}

was set as $\alpha=0.1$. Minimum detectable difference and power of test were indicated and test precision was also evaluated.

\section{Safety evaluation}

Subjective symptoms, objective findings, vital signs (blood pressure, pulse rate, body temperature, respiratory rate), ECG and clinical laboratory examinations were checked.

\section{Results}

\section{Pharmacokinetics}

Plasma concentration profiles of CPFX and pharmacokinetic parameters are shown in Fig. 1 and Tab. 1. Statistical analysis of bioequivalence between fine granule and Ciproxan ${ }^{\otimes}$ tablet are shown in Tab. 2.

Plasma concentration profiles and pharmacokinetic parameters of CPFX were comparable between fine granule and Ciproxan ${ }^{\circledR}$ tablet. The ratios of mean $\mathrm{C}_{\max }$ and $\mathrm{AUC} \mathrm{O}_{-\infty}$ values of fine granule to tablet were $7.18 \%$ and $4.49 \%$ respectively within the range of $20 \%$, which was required in the guideline ${ }^{1)}$, and no significant difference was found between two formulations by ANOVA. Furthermore, the minimum detectable difference was less than $20 \%$, the power of test exceeded $80 \%$, and the precision of the study satisfied the requirements of the guideline. The $90 \%$ confidence intervals of both parameters to tablet were $-5.61 \leq \delta \leq 19.97 \%$ and $-1.18 \leq \delta \leq 10.15 \%$. 


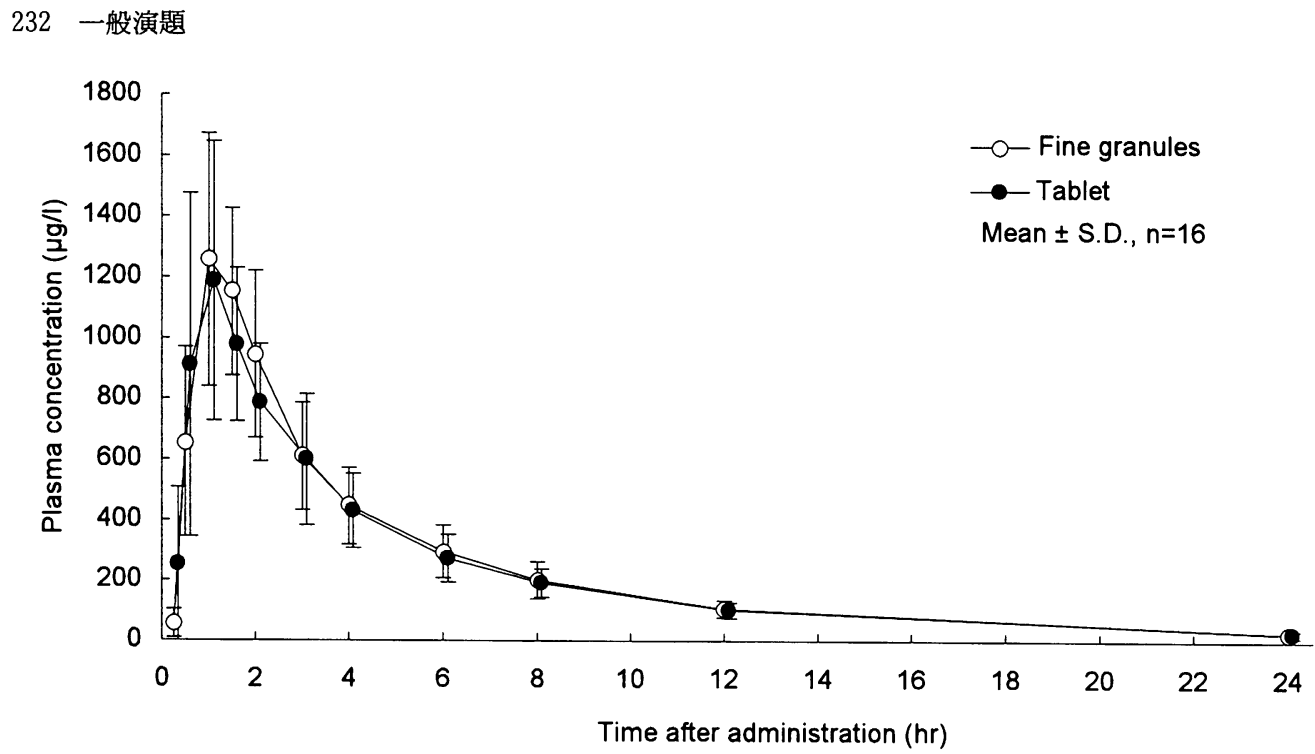

Fig. 1 Plasma Concentration Profiles of Ciprofloxacin

Tab. 1 Pharmacokinetic Parameters of Ciprofloxacin

\begin{tabular}{lccccc}
\hline & $\mathrm{Cmax}[\mu \mathrm{g} / \mathrm{l}]$ & $\mathrm{tmax}[\mathrm{h}]$ & $\mathrm{AUC} 0-\infty[\mu \mathrm{g} \cdot \mathrm{h} / \mathrm{l}]$ & $\mathrm{AUC} 0-\mathrm{t}[\mu \mathrm{g} \cdot \mathrm{h} / \mathrm{l}]$ & $\mathrm{t} / 2[\mathrm{~h}]$ \\
\hline Fine granule & $1437.13 \pm 278.89$ & $1.22 \pm 0.31$ & $5703.91 \pm 1172.59$ & $5353.61 \pm 1229.87$ & $5.48 \pm 1.12$ \\
Tablet & $1340.87 \pm 337.85$ & $1.13 \pm 0.81$ & $5459.00 \pm 1055.25$ & $5107.95 \pm 1066.12$ & $5.60 \pm 1.41$ \\
\hline
\end{tabular}

Mean \pm S.D., $n=16$

Tab. 2 Statistical Analysis of Bioequivalence

\begin{tabular}{|c|c|c|}
\hline & $C_{\max }$ & $\mathrm{AUC}_{0-\infty}$ \\
\hline difference of mean values & $96.27 \mu \mathrm{g} / 1$ & $244.91 \mu \mathrm{g} \cdot \mathrm{h} / 1$ \\
\hline ratio against drug $A$ & $7.18 \%$ & $4.49 \%$ \\
\hline $90 \%$ confidence interval & $-5.61 \leq \delta \leq 19.97 \%$ & $-1.18 \leq \delta \leq 10.15 \%$ \\
\hline minimum detectable difference & $18.99 \%$ & $8.41 \%$ \\
\hline power of test & $83.47 \%$ & $99.99 \%$ \\
\hline
\end{tabular}

\section{$\underline{\text { Safety }}$}

Both CPFX tablet and fine granule were well tolerated. No adverse event was observed. Vital signs, ECG and clinical laboratory tests did not show any clinically relevant changes between pre and post-dose of the drugs.

\section{Conclusions}

Plasma concentration profile of CPFX after dosing of a fine granule formulation was similar to that of Ciproxan ${ }^{\circledR}$ tablet, and bioequivalency could be stated. Two formulations were well tolerated Newly developed CPFX fine granule is expected to show equivalent efficacy and safety as Ciproxan ${ }^{\circledR}$ tablet in clinical use.

\section{References}

1) Ejima, A et al.: IYAKUHIN KENKYU 13 (5) 1106-1119 (1982) 